九州大学学術情報リポジトリ

Kyushu University Institutional Repository

\title{
A LIST OF SOME CHRYSOMELID SPECIMENS COLLECTED IN E. MANCHURIA AND N. KOREA
}

Kimoto, Shinsaku

Kawase, Eiji

https://doi.org/10.5109/2352

出版情報 : ESAKIA. 5, pp.39-48，1966-11-16. Hikosan biological laboratory, Faculty of Agriculture, Kyushu University バージョン：

権利関係 : 


\title{
A LIST OF SOME CHRYSOMELID SPECIMENS COLLECTED IN E. MANCHURIA AND N. KOREA*
}

\author{
BY \\ Shinsaku KımoTo and Eiji KawASE†
}

Kawase, one of the authors, made his trips to N. Korea and E. Manchuria in 1933 through 1934. Collectings were made in Sunkang in E. Manchuria and in Homkyung-pukkb in N. Korea. This paper is a result of the study on the Chrysomelid specimens collected by Kawase.

In 1965, Kimoto had an opportunity to study the Chûjô's types, which were preserved in the Taiwan Agricultural Research Institute, Taipei. In this paper, the authors also give some notes on the types of the Chrysomelid species concerning the Manchurian and Korean faunas.

In connection with this work, authors are much indebted to Prof. K. Yasumatsu, Kyushu University, Dr. S. Asahina, National Institute of Public Health, Tokyo, Dr. J. L. Gressitt, B. P. Bishop Museum, Honolulu, and Miss Sally S. C. Chiu, Taiwan Agricultural Research Institute, Taipei.

\author{
Locality names \\ North-East of China (Manchuria) \\ Sunkang (松江) (= former Chientao Hsien ; 旧䦩島省).
}

Chenanling (鎮安嶺). Laoheishan (老黑山). Laolungkou (老龍 口). Laoyehling

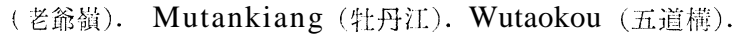

\section{North Korea}

Homkyung-pukkô (咸 鏡北道)

Unggi (跳望). Ôkaja (五家了).

* Contribution Ser. 2, no. 30. Hikosan Biological Laboratory, Kyushu University, Hikosan.

$\uparrow$ Ishikawa Agricultural Experiment Station, Kanazawa. 


\section{Family Chrysomelidae}

\section{Subfamily Donaciinae}

Plateumaris sericea (Linnaeus, 1768)

Korea : Unggi (3 exs., 1. vi. 1934).

This species is recorded for the first time from Korea.

Distribution : Europe, Transcaucasia, Siberia, Saghalien, Korea, Japan.

Donacia japana Chûjồ \& Goecke, 1956

= Donacia aquatica : Chûjô, 1941, Trans. Nat. Hist. Soc. Formosa, 31 (219): 451 (Korea).

Korea : Unggi (1 ex., 1. vi. 1934).

Manchuria : Chenanling (1 ex., 26. vi. 1934).

Châjo, 1941, recorded Donacia aquatica Linnaeus from Korea. However, this should be referred as this species. This species is recorded from Manchuria for the first time.

Distribution : Japan, Korea, Manchuria.

Donacia flemora Goecke, 1944

Korea: Unggi (1 ex., 1. vi. 1934).

Distribution : E. Siberia, Manchuria, Korea.

\section{Subfamily Criocerinae}

Crioceris duodecimpunctata (Scopoli, 1763)

= Crioceris orientalis var. choi Chûjô, 1.941, Trans. Nat. Hist. Soc. Formosa, 31: 452 (Korea).

Manchuria : Chenanling (3 exs., 26. v. 1934).

Coloration of the Manchurian specimens belongs to the duodecastigma type. According to Kimoto's study on the type of Crioceris orientalis var. choi Chûjô, preserved in the Taiwan Agricultural Research Institute, Taipei, this variety is not a variation of orientalis but of C. duodecimpunctata. Thus C. orientalis becomes an endemic species to Japan at present.

Distribution : Europe, Manchuria, Korea.

Crioceris quatuordecimpunetata (Scopoli, 1763)

Korea: Unggi (1 ex., 1. vi. 1934).

Distribution : Europe, Siberia, Manchuria, N. China, Korea, Japan.

\section{Subfamily Clytrinae}

Smaragdina labilis (Weise, 1889)

= Cyaniris corcana Chûjô, 1936, Bull. Umeno Ent. Lab., $3: 7$ (Korea) (new syn.’ 
= Calyptorrhina (Gynandroph thalma) discalis Chû jô, 1941, Trans. Nat. Hist. Soc. Formosa, 31: 454 (new name for Cyaniris coreana Chûjô, nec Kolbe, 1886) (new syn.).

Manchuria : Chenanling (1 ex. 26. v. 1934).

According to Kimoto's study on the type of Cyaniriscoreana Chûjô, preserved in the Taiwan Agricultural Research Institute, coreana Chûjô is no doubt the same as labilis Weise, originally described from N. China.

Distribution : N. China, Manchuria, Korea.

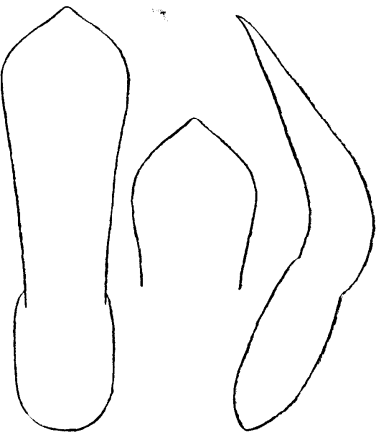

a

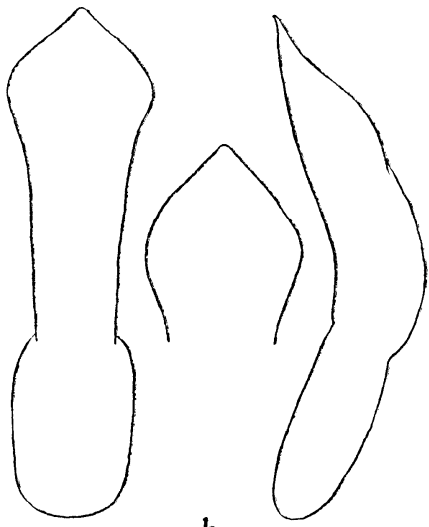

b

Fig. 1. Male genitalia: a, Smaragdina semiaurantiaca (Fairmaire) (specimen from Yablonya, Manchuria); b, S. cyanea (Linnaeusj (specimen from Czechoslovakia).

Smaragdina semiaurantiaca (Fairmaire, 1888)

= Gynandrophthalma (Cyaniris) japonica Fleischer, 1916, Wien. Ent. Zeit. 35: 223 (Japan) (new syn.).

= Gynandrophthalma gawetai Achard, 1921, Bull. Soc. Ent. France, 1921: 61 (new name for G. japonica Fleischerj (new syn.).

= Calyptorrhina (Gynandrophthalma) cyanea subsp. gawetai : Chûjô, 1941, Trans. Nat. Hist. Soc. Formosa, 31 (219): 454 (Korea).

= Smaragdina gaw etai : Kimoto, 1964, Jour. Fac. Agr. Kyushu Univ., 13 (1): 138 (Japan).

Manchuria : Chenanling (3 exs., 26. v. 1934). Mutankiang (1 ex., 1933).

As suggested by Gressitt \& Kimoto (1961, Pac. Ins. Mon. 1A:101), G. garretai (=japonica Fleischer) should be treated as a synonym of semiaurantiaca Fairmaire. This species is separable from S. cyanea (Linnaeus) by having the anterior margin of clypeus and legs entirely pale, and different shape of the male genitalia.

Distribution : N. China, Manchuria, Korea, Japan. 
Smaragdina mandzhura (Jacobson, 1925)

=Cyaniriskusanagii Chûjô, 1940, Trans. Nat. Hist. Soc. Formosa, 30 : 359, fig. 3 (Korea).

According to Kimoto's study on the type of Cyaniriskusanagii Chûjô, preserved in the Taiwan Agricultural Research Institute, this species is no doubt identical with S. mandzhura (Jacobson), originally described from Manchuria.

Distribution : Siberia, Manchuria, N. China, Korea, Japan.

\section{Subfamily Cryptocephalinae}

\section{Cryptocephalus japanus Baly, 1873}

Manchuria : Laoheishan (1 ex., 23. vii. 1933 ; 1 ex., 7. vii. 1933).

Gressitt's and Kimoto's key to C.japamus and jansoni (1961, Pac. Ins. Mon. IA: 125) should be revised as follow :

Pygidium entirely black ; abdomen of male without projections in anterior part of excavation ; pygidium of female nearly straight at apex ; elytron normally with 2 black spots........................................................ jansoni Baly

Pygidium black with apical border pale; abdomen of male with a pair of projections in anterior part of excavation; pygidium of female bilobed at apex ; elytron with four black spots $(2: 2)$, or spotless japanus Baly

According to Kimoto's study at the British Museum (Nat, Hist.), type series of jansoni is wrongly labelled as Cryptocephaluschinensis Baly which is not a published name.

Distribution : Siberia, N. China, Korea, Japan.

\section{Cryptocephalus pustulipes Ménétriès 1836}

Manchuria : Wutaokou (1 ex. 26. vi. 1934).

Distribution : Siberia, N. China, Korea, Japan.

Cryptocephalus multiplex Suff rain, 1860

Korea : Unggi (2 exs., 1. vi. 1934).

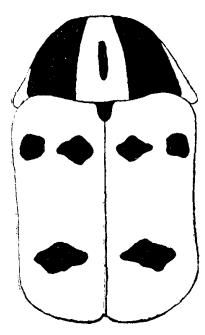

a

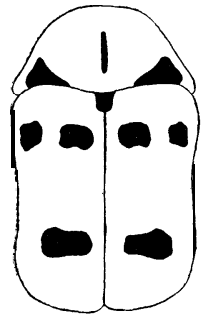

b

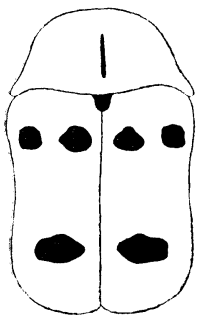

$\mathrm{C}$

Fig. 2. Variation of pronotal markings of Cryptocephalus multiplex Suff rian: a, nominate form: b, transitional form ; c, liothorax Solsky type. 
The specimens taken from Korea before us belong to the liothorax type. However, multiplex Suffrian is a variable species in having the pronotum with blackish marking and there are some tranditional forms as to the pronotal markings.

Distribution : E. Siberia, N. China, Korea.

Cryptocephalus kulibini Gebler, 1832

Manchuria : Laoheishan (1 ex., 7. vii. 1933).

Distribution : Siberia, N. China, Korea.

Cryptocephalus koltzei Weise, 1887

Korea: Unggi (1 ex., 1. vi. 1934).

Manchuria : Mutankiang (1 ex., 1933).

Distribution : Siberia, China, Korea.

Cryptocephalus bohemius semenovi Weise, 1889

Manchuria : Laoheishan (1 ex., 3. vii. 1933 ; 1 ex., 7. viii. 1933).

Distribution : E. Siberia, Mongolia, Manchuria, N. China, Japan.

Cryptocephalus leminiscatus Suff rian, 1854

Manchuria : Wutaokou (1 ex., 26. vi. 1934).

Distribution : Mongolia, Manchuria, N. China.

Cryptocephalus limbatipennis Jacoby, 1885

= Cryptocephalus yanoi Chûjô, 1938, Mushi II : 161, fig. 1 (N. China).

According to Kimoto's study on the type of Cryptocephalus yanoi Chûjô, preserved in the Taiwan Agricultural Research Institute, this species is no doubt identical with C. limbatipennis Jacoby, originally described from Japan.

Distribution : China, Japan.

Cryptocephalus yamadai Chûjô, 1940

Trans. Nat. Hist. Soc. Formosa, 30 (205): 394, fig. 6 (Korea).

= Cryptocephalus ainu Chûjô, 1959, Kagawa Univ., Mem. Fac. Lib. Arts \& Educ. 2 (81): 6 (Japan) (new syn.).

In 1964, Kimoto (Jour. Fac. Agr. Kyushu Univ., 13 (1): 148) suggested that Cryptocephalus ainu Chûjô might be a synonym of C. yamadai Chûjô. According to Kimoto's study on the type of C. yamadai Chûjô, preserved in the Taiwan Agricultural Research Institute, C. yamadai is no doubt identical with C. ainu Chûjô, described from Japan (Hokkaido).

Distribution : Korea, Japan (Hokkaido).

\section{Subfamily Eumolpinae}

Basilepta fulvipes (Motschulsky, 1860)

Manchuria : Laoheishan (1 ex., 7. vii. 1933 ; 1 ex., 17. viii. 1933).

Distribution : Siberia, Mongolia, Manchuria, Korea, China, Japan. 


\section{Subfamily Chrysomelinae}

Chrysomela populi Linnaeus, 1758

Korea : Unggi (2 exs., 1. vi. 1934).

Manchuria : Laoheishan (1 ex., 26. vi. 1933).

Distribution : Europe, Siberia, India, China, Manchuria, Korea, Japan.

Chrysomela vigintipunctata (Scopoli, 1763)

Korea : Ôkaja (1 ex., 1. vi. 1934).

Distribution : Europe, Siberia, China, Taiwan, Korea, Japan.

Phratora inhonesta (Weise, 1884).

Korea : Unggi (1 ex., 1. vi. 1934).

Distribution : S. Siberia, N. Manchuria, Korea, Kuriles.

This species is recorded for the first time from Korea.

Plagiodera versicolora (Laicharting, 1781)

Manchuria : Laolungkou (5 exs., 27. v. 1934). Mutankiang (1 ex., 1933). Laoheishan (2 exs., 29. vii. 1933). Wutaokou (2 exs., 26. vi. 1934).

Distribution : Europe, N. Africa, Siberia, China, Manchuria, Korea, Taiwan, India, Japan, Ryukyu Is.

Chrysolina virgata (Motschulsky, 1860)

Manchuria : Laoheishan (1 ex., 17. x. 1933).

Distribution : E. Siberia, Manchuria, N. China, Korea, Quelpart I., Japan.

Chrysolina exanthematica (Wiedemann, 1821)

Manchuria : Laoheishan (1 ex., 5. ix. 1934).

Distribution : Siberia, Manchuria, China, Korea, India, Japan.

Chrysolina aurichalcea (Mannerheim, 1825)

*Manchuria : Laoheishan (2 exs., 17. x. 1933).

Distribution : Siberia, Mongolia, China, Tonkin, Burma, Taiwan, Korea, Manchuria, Saghalien, Japan, Ryukyu Is.

Chrysolina sulcicollis (Fairmaire, 1887)

Rev. d'Ent. $6: 330$ (Pekin)(Chrysomela).

=Chrysolina koreana Chûjô, 1941, Trans. Nat. Hist. Soc. Formosa, 31 (209) : 68, fig. 8 (Korea) (new syn.).

= Chrysolina sulcicollis koreana: Gressitt \& Kimoto, 1963, Pac. Ins. Mon. 1B: 323.

According to Kimoto's study on the type of C. koreana Chûjô, preserved in the Taiwan Agricultural Research Institute, Chrysolinakoreana Chûjô should not be separated from the nominate form.

Distribution : W. China, Manchuria, Korea.

6onioctena sunkangensis Kimoto and Kawase, n. sp.

Head, underside and scutellum black to piceous; antennae piceous with three 
or four basal joints pale; legs black with tibiae dark reddish brown; pronotum reddish brown, but in many specimens with a pair of basal markings, which are touching each other in middle but not reaching lateral margins; elytra reddish brown, but in many specimens with five pairs of blackish markings, viz., subbasal, postero-median, humeral, latero-median and latero-subapical ones.

$c$ : Vertex closely impressed with distinct punctures, especially so on lateral area and their interstices shagreened ; fronto-clypeus depressed, delimited behind by a pair of shallow, oblique grooves. Antennae slender, comparing with most of the species of the genus, first robust, long, second shorter than first and nearly twice as long as wide, third longest, nearly twice as long as second, fourth nearly half as long as third, fifth to tenth subequal to each other in length but gradually widened towards the apical joints, eleventh long, nearly as long as third, but its apex pointed. Pronotum transverse, twice as broad as long; anterior margin distinctly emarginate but almost straight at median portion; lateral margins rounded, widest at $1 / 5$ to $1 / 6$ from basal corner and narrowed anteriorly and posteriorly ; posterior margin rounded posteriorly at median portion ; dorsal surface closely impressed with large punctures laterally and sparsely with much smaller ones medially, and their interstices impressed with minute punctures and fine strigose. Scutellum as long as wide and its posterior margin rounded, surface impunctate, wrinkled. Elytra subparallel-sided, with regulary arranged eleven longitudinal rows of punctures, and their interstices closely impressed with distinct punctures.

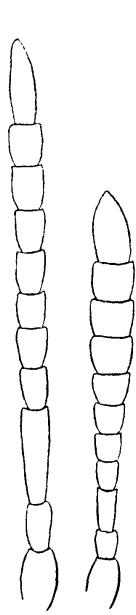

a

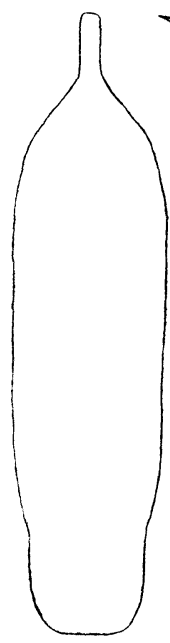

c

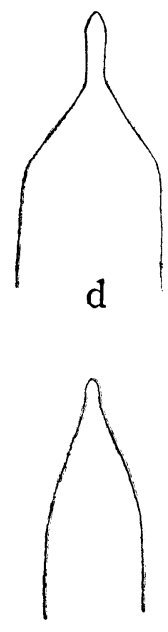

e

Fig. 3. a-b, antennae, c e, male genitalia: a, Gonioctena(Gonioctena) sunkangensis Kimoto and Kawase, n. sp. $\sigma^{\top}$, b, ibid., + , c, ibid, 乃7; d, G. (G.) coreana (Bechyně) (after Bechyně, 1947); e, G. (G.) gracilicornis (Kraatz) (after Bechyně, 1947). 
ㅇ: Antennae much robuster than male, first robust and longest, second robust, but much shorter than first, third nearly $11 / 2$ times as long as second but more slender than second, fourth subequal to second in length but more slender, fourth to sixth subequal in length to each other but robuster towards the apical joints, seventh slightly longer than sixth, eighth to tenth subquadrate, subequal in length and shape to each other, eleventh long, subequal in length to first and its apex pointed.

Length : $7.0-8.0 \mathrm{~mm}$.

Holotype : Laoheishan (17. x. 1933, E. Kawase leg.) (Entomological Laboratory, Kyushu University, Fukuoka).

Paratopotype : I ex., same as the holotype.

Paratypes : 3 exs., Wutaokou (26. vi. 1934, E. Kawase leg.). 1 ex., Laoyehling (3. vi. 1934, E. Kawase leg.).

This new species is closely resembling Gonioctena coreana Bechyně but clearly separable from the latter in having the truncate apex of male genitalia instead of pointed one. Also from G. gracilicornis Kraatz, this new species is separable in having the parallel-sided subapical to apical portion of male genitalia, instead of gradually narrowed subapical to apical portion.

Gressitt and Kimoto (1963, Pac. Ins. Mon. 1B: 361) identified one specimen from “ Tschen, Mandschurei, 24. ix. 1944," preserved in the Museum G. Frey, as Gonioctenacoreana Bechyně with some doubt. However, this should be referred as this new species. Also, three additional female specimens from Hsining, Manchuria, are possibly referable here but still doubtful because they are all female specimens.

Distribution : Manchuria.

\section{Subfamily Galerucinae}

Lochmaea capreae (Linnaeus, 1758)

Manchuria : Laolungkou (1 ex., 27. v. 1934). Laoheishan (1 ex., 17. x. 1933).

Distribution : Europe, Siberia, N. China, Manchuria, Ko rea, Japan.

Galerucella grisescens (Joannis, 1866)

Manchuria : Laoheishan (3 exs., 7. viii. 1933).

Distribution : Taiwan, Ryukyu Is., Japan, Korea, China, Manchuria, Siberia, Saghalien.

Phyllobrotica signata (Mannerheim, 1825)

= Taumacera (Cerophysa) parasuturalis Gressitt \& Kimoto, 1963, Pac. Ins. Mon. 1B: 524 (Manchuria, E. Siberia).

Manchuria : Laoheishan (1 ex., 21. vi. 1933).

As treated by Gressitt \& Kimoto (1965, Pac. Ins. 7 (4) : 801), Taumarcra (Cerophysa) parasuturalis G. \& K. is a synonym of Phyllooroticasignata.

Distribution : Siberia, N. China, Mongolia, Manchuria, Korea. 
Xulacophora femoralis (Motschulsky, 1857)

Manchuria : Laoheishan (1 ex., 17. x. 1933).

Distribution : Japan, Ryukyus, Korea, Manchuria, China, Taiwan.

Monolepta quadrigutiatum (Motschulsky, 1860)

Manchuria: Laoheishan (I ex., 12. viii. 1933 ; 1 ex., 9. viii. 1933 ; 1 ex., 17. viii. 1933 ; 1 ex., 7. viii. 1933).

Distribution : E. Siberia, Manchuria, Korea, Quelpart I., Japan.

Agelastica coerulea Baly, 1860

Manchuria: Chenanling (1 ex., 26. v. 1934).

Distribution: Japan, Korca, Manchuria, E. Siberia, N. America.

Gallerucida bifasciata Motschulsky, 1860

Manchuria : Laoyehling (1 ex., 3. vi. 1934).

Distribution : E. Siberia, Manchuria, China, Korea, Taiwan, Japan.

Exosoma nigriventris (Ogloblin, 1936)

Manchuria : Laoheishan (1 ex., 17. vii. 1933).

One additional female specimen from Laoheishan ( 7. viii. 1933 ) is probably this species.

Distribution : N. China, Manchuria.

\section{Subfamily Alticinae}

Luperomorpha suturalis Chen, 1938

Manchuria : Chenanling (2 exs., 26. v. 1931). Laolungkou (1 ex., 27. v.1931).

Distribution : E. China, Manchuria.

Luperomorpha xanthodera (Fairmaire, 1888)

=Luperomorpha similis Chûjô, 1938, Mushi11(2): 166, fig. 2 (N. China).

Chen (1954, Acta Ent. Sinica 4 (1): 96) treated similis as a subspecies of suturalis Chen and Gressitt and Kimoto (1963, Pac. Ins. Mon. 1B: 864) as a synonym of Luperomorphaxanthodera (Fairmaire). According to Kimoto's study on the type of $L$. similis Chûjô, this species is no doubt identical with Luperomorpha xanthodera (Fairmaire).

Distribution : China, Manchuria.

\section{Subfamily Hispinae}

Dactylispa masonii Gestro, 1923

Korea : Unggi (1 ex., 1. vi. 1934).

*Manchuria : Chenanling (2 exs., 26. v. 1934). Laolungkou (1 ex., 2i. v. 1934). 
Above listed four specimens belong to the rufescens type (Shirôzu, 1957, Sieboldia 2: 55, pl. 6, fig. 3) in having the entirely blackish abdomen. This species is recorded from Korea for the first time.

Distribution : China, Manchuria, E. Siberia, Korea, Japan. 